\title{
Control of Indoor climate of Historical cult buildings
}

\author{
Martins Metals ${ }^{1 *}$, Arturs Lesinskis ${ }^{1}$, and Kristaps Turauskis ${ }^{1}$ \\ ${ }^{1}$ Riga Technical university, Institute of Heat, Gas and Water technology, Kipsalas street 6A, Riga, Latvia, LV-1048
}

\begin{abstract}
There are 320 historical cult buildings as cultural monuments of national significance in Latvia. Cultural and historical art monuments and artifacts (paintings, organs, chairs, altars, pulpits) must be preserved and protected in these cultural buildings. Specific indoor climate is necessary to maintain in historical cult buildings to pass on to future generations, but those specific requirements often are complete opposite of the actual microclimate and what the user wants.

Indoor climate measurements have been carried out in five brick wall and two wooden churches with and without heating systems. Potential condensation risks are determined using calculations. Typical air flow has been formed using building's termography measurements. Heating systems and making use of buildings influence historical buildings and this has been determined. The main aim of the article is to determine potential indoor climate type of control in historical cult buildings avoiding humidification and dehumidification, and it is similar in the coastal climate of the Baltic Sea.

Results show that: great humidity fluctuations have been observed in buildings which have been used during winter, outdoor air has a great impact to buildings, less humidity fluctuations have been observed in buildings with controlled heating systems.
\end{abstract}

\section{Introduction}

Historic churches constitute an important part of European cultural heritage. Buildings and their interiors, including liturgical objects and artefacts, attest to our cultural heritage and must be preserved for future generations. Microclimate is a crucial factor in allowing the preservation of buildings and the artefacts in them. An unsuitable interior microclimate may cause irreversible loss.

According to data provided by the National Culture Heritage Administration (NKMP, until 2020 the former State Inspectorate for Heritage Protection) in Latvia:

- There are 226 cult buildings with the status of monument of national significance (incl. churches, cathedrals, synagogues, prayer houses);

- There are 1,385 movable art monuments of national significance (incl. paintings, tableware etc.) located in the cult buildings;

- There are 993 immovable art monuments of national significance (incl. altars, various benches, organs, pulpits, interior and "exterior" details) located in cult buildings [1].

The discussion resolution of a seminar organized by the State Inspectorate for Heritage Protection on 29 July 2008 states: "To ensure the comfort of church visitors, more and more often church building managers wish to install heating in churches. The choice of heating system is often not based on its impact on the monument, but rather following the recommendations of construction companies and forceful advertisements for heating systems which aim at a quick profit instead of the preservation of the building. [2]"

Initially, historic churches more than 300 hundred years old were not heated. Back then, requirements of church visitors were much lower than today [2]. Visitors would put on cloth caps, felt boots, mittens, and other warm clothing, and vessels used for the Blessed Sacrament were made of silver so that they could be used in cold temperatures. In other words, the church visitors initially took care of their own microclimate.

Since then, the growing needs of church visitors have required a more favorable environment inside church buildings. At the same time, the economic possibilities and activities of church owners and managers have increased. The market offers versatile indoor climate control products. However, sufficient information about their suitability for solving a particular problem is often not available. Selected solutions do not always meet the building maintenance requirements i.e.:

- In such buildings, historic windows and doors are frequently not allowed to be replaced with new ones, and overhaul also is not permitted, which would reduce heat and air permeability because windows often have a separate status as cultural monuments of national significance [2].

- Buildings with the status of architectural monument of national significance may not be heat-insulated or undergo a change of façade [2].

According to data provided by the NKMP regarding movable and immovable art monuments in churches, one can see that church interiors constitute a considerable part of the cultural heritage in need of specific climate maintenance and control.

It must be noted that churches built 300 year ago and earlier were subject to very different construction techniques and principles of use, as compared to nowadays:

1. The foundations of a building were not waterproofed, and therefore its walls and columns were unprotected from the impact of capillary and atmospheric precipitation [3];

2. Parts of a building's brick structure were built with lime mortar, which ensured the exchange of various substances. Thus, they effectively drain away moisture absorbed through the foundations [3];

3. For many churches (especially urban ones) surrounding cultural layer has elevated the ground level (pedestrian paths, squares etc.) by several meters, which originally had been close to the ground floor level of the church [3].

So far, the requisite building microclimate has not been defined, and the most suitable types of microclimate control have also not been identified.

Martins Metals e-mail: metaals@latnet.lv 
The standard AVOK (ABOK) - 2 - 2004 „Orthodox churches. Heating, ventilation and air conditioning" elaborated by the Russian Federation determines:

- Heating and ventilation must be installed in churches that are used all year round,

- The microclimate parameters of these churches must be ensured according to the season and the classification of their premises based on their use,

- In cold and transitional periods (autumn, spring) RH (relative humidity) must be $30 \%-45 \%$ and air temperature $12^{\circ}-18^{\circ} \mathrm{C}$

Meanwhile, according to the Russian Federation Building Standard SNiP (СНиП) 31-103-99 „Orthodox Church buildings, structures and complexes", the calculation of air temperature in the hall must be $14^{\circ} \mathrm{C}$, in the middle part of the church it must be $16^{\circ} \mathrm{C}$, at the alter it must be $18^{\circ} \mathrm{C}$ and in the baptism room it must be $22^{\circ} \mathrm{C}$. If the annual average air moisture in Liepaja (LV) $78.8 \%$ and Riga (LV) $75.2 \%$ is compared against the average air humidity in Volgograd (RUS) $58 \%$, it can be concluded that Latvia's climate differs, and the Russian Federation Standard is not fully applicable to Latvia [5].

T. Brostrom and J. Hanson made measurements in nine churches of the Baltic Region: Lau, Gotland (S), Oja, Gotland (S), Vaskinde, Gotland (S), Kaarma, Saaremaa (EST), Poide, Saaremaa (EST), Valjala, Saaremaa (EST), Kandava (LV), Tukums (LV), Dzirciems (LV). According to the measurements taken, the study found that the best and most stable indoor climate was in Oja Church which was nevertheless one of the most expensive in operation. Oja Church has intermittent (periodic) heating where the $\mathrm{RH}$ fluctuation interval during a year varies between $55 \%-75 \%$, whereas air temperature fluctuates between $8{ }^{\circ} \mathrm{C}-23^{\circ} \mathrm{C}$ [4]. This study does not examine the heat accumulation properties of brick wall constructions and the risks of condensation. Considering the vast heat accumulation potential of brick structures, a church with intermittent heating may possibly use equivalent or even higher energy consumption than a church which has permanent conserved heating. Potential condensation risks can be reduced with permanent conserved heating.

During their research of three churches, D.O. Sovetnikov, D.V. Baranova, A. Borodinecs, and S.V. Korniyenko came to the conclusion that in these churches "The result of thermal analysis shows that $75 \%$ of heat loss emerges through a flat element and $25 \%$ through thermal bridges. The bigger part of supplementary heat loss was found through the horizontal linear element (17 $\%$ ) and the smaller part - through the vertical linear element (8\%)" [5].
It is often the case that condensate formation in churches is caused by a lack of heat insulation, and in order to prevent it one needs to improve heat insulation of the dome [6]. Public buildings have some experience showing that heat insulation of the building envelope, if not accompanied by a reconstruction of the ventilation system, gives rise to elevated $\mathrm{CO} 2$ concentration [7]. Meanwhile, if we consider cult buildings on a par with public buildings, we can expect similar results. Therefore, we will not propose the total heat insulation of the building envelope, which would also contradict the regulations governing the conservation of these monuments [13]. Evaluating the possible ventilation systems, it is established that the cheapest ventilation systems provide the least automation and control, and also represent the worst indoor climate [8]. Since the cheapest ventilation systems might fail to provide the necessary microclimate in the cult buildings, and since the most expensive ventilation systems are often unaffordable due to financial restrictions, we will not consider forced ventilation systems in our research. Ventilation by virtue of automated opening of windows and doors can ensure better and more stable indoor air parameters, while opening the windows when indoor air is too humid and outside air is drier [9].

M. Napp and T. Kalmes performed measurements in the Church of the Holy Cross (EST) with three various climate control methods (adaptive ventilation, conservation heating and dehumidification) and concluded: "Conserved heating with a heat pump showed the lowest annual energy consumption of $29 \mathrm{kWh} /(\mathrm{m} 2 \cdot \mathrm{a})$. The energy consumption also depends on the outdoor climate: dehumidification is most effective during cold periods and the conserved heating is most effective during warm periods. [10]" In view of other studies $[5 ; 6 ; 7 ; 9]$ this type of building has massive outdoor air infiltration during the cold season, so that in the cold (winter) period the air should not be dried and kept at a constant minimum temperature $\left(+6^{\circ}\right)$ instead, thus ensuring that the air does not become too dry during the cold season.

When defining possible microclimate risks, the main goal is to identify the possible microclimate control type for a historic cult building by using only constant conserved heating without forced air humidification and drying or other types of mechanical ventilation.

\section{Methods}

\subsection{Summary of church descriptions}

Table 1. Summary of architectural and civil engineering characteristics

\begin{tabular}{|c|c|c|c|c|c|c|c|}
\hline Church & Age & Heating type & Zoning & $\begin{array}{c}\text { Heating } \\
\text { elements }\end{array}$ & $\begin{array}{c}\text { Structural } \\
\text { solution of } \\
\text { walls }\end{array}$ & $\begin{array}{c}\text { Structural } \\
\text { solution of } \\
\text { ceilings }\end{array}$ & $\begin{array}{c}\text { Structural } \\
\text { solution of } \\
\text { floors }\end{array}$ \\
\hline Limbazi & 1680 & Local heating & Altar room & none & $\begin{array}{c}\text { Granite boulder } \\
\text { masonry walls } \\
\mathrm{b}=1.4 \mathrm{~m}\end{array}$ & $\begin{array}{c}\text { Brick vaults } \\
\mathrm{b}=140 \mathrm{~mm}\end{array}$ & $\begin{array}{c}\text { Wood deck } \\
\text { floor on } \\
\text { ground }\end{array}$ \\
\cline { 4 - 7 } & & & Parish hall & $\begin{array}{c}\text { infrared } \\
\text { lamps }\end{array}$ & $\begin{array}{c}\text { Granite boulder } \\
\text { masonry walls } \\
\mathrm{b}=1.0 \mathrm{~m}\end{array}$ & $\begin{array}{c}\text { Wooden deck } \\
\text { ceiling with } \\
\text { lime plaster }\end{array}$ & $\begin{array}{c}\text { Wooden } \\
\text { deck floor on } \\
\text { ground }\end{array}$ \\
\hline
\end{tabular}




\begin{tabular}{|c|c|c|c|c|c|c|c|}
\hline & & & & & & $\begin{array}{l}\text { and sand } \\
\text { insulation }\end{array}$ & \\
\hline \multirow[t]{2}{*}{ Krimulda } & \multirow[t]{2}{*}{1204} & \multirow[t]{2}{*}{$\begin{array}{c}\text { Irregular } \\
\text { heating }\end{array}$} & Altar room & none & $\begin{array}{c}\text { Granite } \\
\text { masonry walls } \\
\mathrm{b}=1.8 \mathrm{~m}\end{array}$ & $\begin{array}{c}\text { Brick vaults } \\
\mathrm{b}=140 \mathrm{~mm}\end{array}$ & $\begin{array}{l}\text { Brick-paved } \\
\text { floor }\end{array}$ \\
\hline & & & Parish hall & $\begin{array}{l}\text { pig-iron } \\
\text { stove }\end{array}$ & $\begin{array}{c}\text { Granite } \\
\text { masonry walls } \\
\mathrm{b}=1.5 \mathrm{~m}\end{array}$ & $\begin{array}{l}\text { Wooden deck } \\
\text { ceiling with } \\
\text { glass fleece } \\
\text { insulation }\end{array}$ & $\begin{array}{l}\text { Brick-paved } \\
\text { floor }\end{array}$ \\
\hline \multirow[t]{2}{*}{ Cesis } & \multirow[t]{2}{*}{$\begin{array}{c}1282- \\
1287\end{array}$} & \multirow{2}{*}{$\begin{array}{c}\begin{array}{c}\text { Permanent gas } \\
\text { heating }\end{array} \\
\text { (VIESSMANN, } \\
\text { VITODENS } \\
300, \mathrm{~N}=60 \mathrm{Kw} \text {. } \\
\text { Thermal load } \\
\text { for hot water } \\
\text { heating } 6.8 \mathrm{~kW} \text { ) }\end{array}$} & Altar room & $\begin{array}{c}\text { radiator } \\
\text { heating for } \\
\text { adjacent } \\
\text { rooms } \\
25.9 \mathrm{~kW} \\
\end{array}$ & $\begin{array}{c}\text { Dolomite } \\
\text { masonry walls } \\
\mathrm{b}=1.8 \mathrm{~m}\end{array}$ & $\begin{array}{c}\text { Brick vaults } \\
\mathrm{b}=140 \mathrm{~mm}\end{array}$ & $\begin{array}{l}\text { Wooden } \\
\text { deck floor }\end{array}$ \\
\hline & & & Parish hall & $\begin{array}{c}\text { heated floors } \\
27.2 \mathrm{~kW}\end{array}$ & $\begin{array}{c}\text { Granite } \\
\text { masonry walls } \\
b=1.5 \mathrm{~m}\end{array}$ & $\begin{array}{l}\text { Wooden deck } \\
\text { ceiling with } \\
\text { glass fleece } \\
\text { insulation }\end{array}$ & Tile floor \\
\hline $\begin{array}{c}\text { Liepaja St. } \\
\text { Trinity }\end{array}$ & 1758. & $\begin{array}{c}\text { Municipal } \\
\text { heating } \\
\text { networks (heat } \\
\text { exchanger } \\
250 \mathrm{~kW} \text { ) }\end{array}$ & Common & Radiators & $\begin{array}{c}\text { Brick wall } \\
\mathrm{b}=0,67-1,29 \mathrm{~m}\end{array}$ & $\begin{array}{c}\text { Rib brick } \\
\text { vaults } \\
\mathrm{b}=140 \mathrm{~mm}\end{array}$ & $\begin{array}{l}\text { Wooden } \\
\text { deck floor }\end{array}$ \\
\hline \multirow[t]{2}{*}{$\begin{array}{c}\text { Kuldiga St. } \\
\text { Anne }\end{array}$} & \multirow[t]{2}{*}{1904} & \multirow{2}{*}{$\begin{array}{c}\text { Firewood } \\
\text { heating } \\
\text { (Kronbergs\& } \\
\text { Kronbergs) } \\
120 \mathrm{~kW}\end{array}$} & Altar room & $\begin{array}{l}\text { Warm air } \\
\text { heating } \\
\text { channels }\end{array}$ & Red brick wall & $\begin{array}{c}\text { Rib brick } \\
\text { vaults }\end{array}$ & $\begin{array}{l}\text { Wooden } \\
\text { deck floor }\end{array}$ \\
\hline & & & Parish hall & $\begin{array}{l}\text { Warm air } \\
\text { heating } \\
\text { channels }\end{array}$ & Red brick wall & $\begin{array}{c}\text { Rib brick } \\
\text { vaults }\end{array}$ & $\begin{array}{l}\text { Wooden } \\
\text { deck floor }\end{array}$ \\
\hline Matthew & 1902 & $\begin{array}{c}\text { Municipal } \\
\text { heating } \\
\text { networks (heat } \\
\text { exchanger } \\
181 \mathrm{~kW} \text { ) } \\
\end{array}$ & Parish hall & Heated floor & $\begin{array}{l}\text { Yellow brick } \\
\text { wall }\end{array}$ & Wooden slab & Tile floor \\
\hline Turaida & 1750 & Locally & Common & None & $\begin{array}{c}\text { Horizontal } \\
\text { beam } b=200 \mathrm{~mm}\end{array}$ & $\begin{array}{c}\text { Wooden slab } \\
\mathrm{b}=150 \mathrm{~mm}\end{array}$ & $\begin{array}{l}\text { Wooden } \\
\text { deck floor }\end{array}$ \\
\hline Riga Jesus & 1822 & $\begin{array}{l}\text { Municipal } \\
\text { heating } \\
\text { networks }\end{array}$ & Common & $\begin{array}{l}\text { Pig-iron } \\
\text { radiators }\end{array}$ & $\begin{array}{c}\text { Horizontal } \\
\text { beam } b=200 \mathrm{~mm}\end{array}$ & $\begin{array}{c}\text { Wooden slab } \\
\mathrm{b}=150 \mathrm{~mm}\end{array}$ & $\begin{array}{l}\text { Wooden } \\
\text { deck floor }\end{array}$ \\
\hline
\end{tabular}

\subsection{Condensation risks}

3. Condensation risks are analyzed at three room air temperatures $\left(6^{\circ} ; 12^{\circ} ; 18^{\circ} \mathrm{C}\right)$ and three $\mathrm{RH}(40 \% ; 60 \%$; $80 \%$ ). A Mollier Diagram was used to determine condensation temperature at all previously mentioned parameters which were summarized in Table 2 .

Table 2. Condensation Tc risks at room temperatures $\Theta i$ and relative air humidity $\varphi$

\begin{tabular}{|l|c|c|c|}
\hline $\begin{array}{c}\text { Average room temperatures } \\
\Theta i\end{array}$ & $\begin{array}{c}\mathrm{RH} \\
\varphi 1 \\
40 \%\end{array}$ & $\begin{array}{c}\mathrm{RH} \\
\varphi 2\end{array}$ & $\begin{array}{c}\mathrm{RH} \\
\varphi 3\end{array}$ \\
\hline $\begin{array}{l}\text { Oi1 Average room } \\
\text { temperature } 6{ }^{\circ} \mathrm{C} ;\end{array}$ & -6.5 & -1.8 & 2.5 \\
\hline $\begin{array}{l}\text { Oi2 Average room } \\
\text { temperature } 12^{\circ} \mathrm{C} ;\end{array}$ & -1.8 & 4.5 & 8.5 \\
\hline $\begin{array}{l}\text { Oi3 Average room } \\
\text { temperature } 18^{\circ} \mathrm{C} ;\end{array}$ & 3.5 & 10.0 & 14.5 \\
\hline
\end{tabular}

Since the stone and wooden buildings have completely different thermal properties, we divided churches into two types - wooden and brick wall - to assess the risks as scrupulously as possible.

\subsubsection{Temperatures of brick wall church building envelopes}

Since the research applies to historic cult buildings, it can be clearly asserted that brick building walls older than 500 years are thicker than 1 meter and ceiling vaults are kept to a thickness of a half-brick (late Medieval halfbrick) Knowing that Cesis and Krimulda churches (Table 1) have $1.6 \mathrm{~m}$ thick walls and a half-brick of the ceiling vaults is $0.14 \mathrm{~m}$, heat resistance $R_{0}$ of walls and ceilings were calculated:

$$
\begin{gathered}
R_{o}=R_{S I}+\delta_{1} / \lambda_{1}+\ldots+\delta n / \lambda_{n+} R_{S E} \\
\operatorname{Ro}(\text { walls })=1.06 \mathrm{~m}^{2} \mathrm{~K} / \mathrm{W} \\
\text { Ro(ceilings) }=0.29 \mathrm{~m}^{2} \mathrm{~K} / \mathrm{W}
\end{gathered}
$$

Based on the foregoing, the temperatures were calculated on the wall, corner of external wall, ceilings, corner between the ceiling and wall and external wall forming a corner with the ceiling, see Table 3. 
Table 3. Temperatures of the building envelope of the brick wall church at the coldest five-days external temperature in Priekuli minus $22.3^{\circ} \mathrm{C}[11]$.

\begin{tabular}{|c|c|c|c|}
\hline & \multicolumn{3}{|c|}{$\begin{array}{l}\mathrm{T}^{\circ} \text { of the building } \\
\text { envelope surface at: }\end{array}$} \\
\hline & 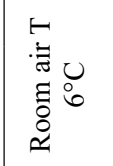 & 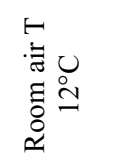 & 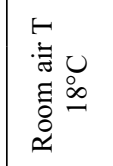 \\
\hline \multicolumn{4}{|l|}{$\mathbf{T}^{\circ}$ on the wall } \\
\hline$T_{i w}=\theta i-R s i / R o(\theta i-\theta e)=$ & $2.35^{\circ} \mathrm{C}$ & $7.61^{\circ} \mathrm{C}$ & $12.88^{\circ} \mathrm{C}$ \\
\hline \multicolumn{4}{|c|}{$\mathrm{T}^{\circ}$ in the corner of external wall } \\
\hline$\tau 2 p / w=T_{i w}-5,55=$ & $-3.2^{\circ} \mathrm{C}$ & $2.06^{\circ} \mathrm{C}$ & $7.33^{\circ} \mathrm{C}$ \\
\hline \multicolumn{4}{|l|}{$T^{\circ}$ on the ceiling } \\
\hline$T_{i c}=\theta i-R s i / R o(\theta i-\theta e)=$ & $-7.46^{\circ} \mathrm{C}$, & $-4.17^{\circ} \mathrm{C}$ & $-0.88^{\circ} \mathrm{C}$ \\
\hline \multicolumn{4}{|c|}{ Reduced $\mathrm{T}^{\circ}$ of external wall joint per plane } \\
\hline $\operatorname{Tirw}=\left(\mathcal{T}_{2} p / w+\operatorname{Tic}_{i c}\right) / 2=$ & $-5.33{ }^{\circ} \mathrm{C}$, & $-1.05^{\circ} \mathrm{C}$ & $3.22{ }^{\circ} \mathrm{C}$ \\
\hline \multicolumn{4}{|c|}{ External and three-plane ceiling joint $\mathrm{T}^{\circ}$} \\
\hline$\tau_{3 p l}=T_{i r w}-\tau_{s v}=$ & $-10.73^{\circ} \mathrm{C}$ & $-6.45^{\circ} \mathrm{C}$ & $-2.18^{\circ} \mathrm{C}$ \\
\hline
\end{tabular}

\subsubsection{Temperatures of wooden church building envelopes}

Since the thickness of walls of all historic trimmed horizontal beam cult buildings is $\sim 200 \mathrm{~mm}$, not exceeding $250 \mathrm{~mm}$, which can be explained by parameters of timber (off- cut slab, spigot and length of log), the thickness of walls examined in this paper is $0.2 \mathrm{~m}$, and the ceiling slab is made of wide-edge wooden beams, cladding with sand and clay mixture filling above it. Knowing that the thickness of walls in Turaida and Riga Jesus Church (Table 1) is $0.2 \mathrm{~m}$ and the ceiling slab has sand filling of $0.15 \mathrm{~m}$, heat resistance $R_{0}$ of walls and ceilings were calculation:

$$
\begin{gathered}
R o(\text { walls })=2.73 \mathrm{~m}^{2} \mathrm{~K} / \mathrm{W} \\
R o(\text { ceilings })=1.04 \mathrm{~m}^{2} \mathrm{~K} / \mathrm{W}
\end{gathered}
$$

Based on the foregoing, temperatures on the wall, corner of external wall, ceilings, corner between ceiling and wall and external wall forming a corner with the ceiling were calculated, see table 4 .

Table 4. Temperatures of the building envelope of wooden church at the coldest five-days external temperature in Priekuli minus $22.3^{\circ} \mathrm{C}[11]$.

\begin{tabular}{|c|c|c|}
\hline$T i c=\theta i-R s i / R o(\theta i-\theta e)=$ & $2.28^{\circ} \mathrm{C}$ & \begin{tabular}{l|l}
$7.53^{\circ} \mathrm{C}$ & 12.78 \\
\end{tabular} \\
\hline \multicolumn{3}{|c|}{ 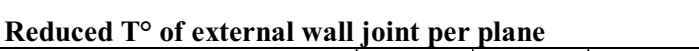 } \\
\hline$T_{i r w}=\left(T_{2 p} / w+T_{i c}\right) / 2=$ & $0.65^{\circ} \mathrm{C}$ & $6.14^{\circ} \mathrm{C} 11.62{ }^{\circ} \mathrm{C}$ \\
\hline \multicolumn{3}{|c|}{ External and three-plane ceiling joint $\mathrm{T}^{\circ}$} \\
\hline$\tau_{3 p} l=\tau_{i r w}-\tau_{s v}=$ & $-4.75^{\circ} \mathrm{C}$, & $\begin{array}{lll}0.74{ }^{\circ} \mathrm{C} & 6.22 \mathrm{C}\end{array}$ \\
\hline
\end{tabular}

\begin{tabular}{|l|l|}
\cline { 2 - 3 } \multicolumn{1}{c|}{} & \multicolumn{3}{|c|}{$\mathrm{T}^{\mathrm{o}}$ of the building } \\
envelope surface at:
\end{tabular}

\subsection{Measurements}

\subsubsection{Microclimate measurements were taken in 7 churches.}

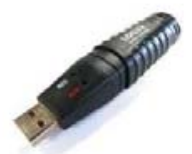

Figure 1. Measuring Device LOG32.

In Krimulda, Cesis St. John and Limbazi Church the measurements were taken with measuring device LOG32, having measuring accuracy $\pm 3 \%$ for $\mathrm{RH}$ and $\pm 1{ }^{\circ} \mathrm{C}$ for $\mathrm{T}$.

Table 5. Time and place of LOG 32 measurements

\begin{tabular}{|l|l|l|l|}
\hline \multicolumn{1}{|c|}{ Church } & \multicolumn{1}{|c|}{$\begin{array}{c}\text { Location of the } \\
\text { measuring device }\end{array}$} & $\begin{array}{c}\text { Inter } \\
\text { val }\end{array}$ & Period \\
\hline $\begin{array}{l}\text { Limbazi (Measuring } \\
\text { Device No.1) }\end{array}$ & $\begin{array}{l}3.5 \mathrm{~m} \text { above the ground } \\
\text { on the pulpit's roof }\end{array}$ & $2 \mathrm{~h}$ & $\begin{array}{l}2013.10- \\
2015.01 .\end{array}$ \\
\hline $\begin{array}{l}\text { Limbazi (Measuring } \\
\text { Device No.2) }\end{array}$ & $\begin{array}{l}\text { 1m above the floor at } \\
\text { the first line of benches } \\
\text { in the hall }\end{array}$ & $2 \mathrm{~h}$ & $\begin{array}{l}2013.10- \\
2015.01 .\end{array}$ \\
\hline $\begin{array}{l}\text { Krimulda (Measuring } \\
\text { Device No.1) }\end{array}$ & $\begin{array}{l}3.5 \mathrm{~m} \text { above the ground } \\
\text { on the pulpit's roof }\end{array}$ & $1 \mathrm{~h}$ & $\begin{array}{l}2012.01- \\
2012.02 .\end{array}$ \\
\hline $\begin{array}{l}\text { Krimulda (Measuring } \\
\text { Device No.2) }\end{array}$ & $\begin{array}{l}3.5 \mathrm{~m} \text { above the ground } \\
\text { on the pulpit's roof }\end{array}$ & $1 \mathrm{~h}$ & $\begin{array}{l}2012.02- \\
2012.05 .\end{array}$ \\
\hline Cesis & $\begin{array}{l}2.5 \mathrm{~m} \text { above the ground } \\
\text { on the pulpit's edge }\end{array}$ & $1 \mathrm{~h}$ & $\begin{array}{l}2012.01- \\
2012.05 .\end{array}$ \\
\hline
\end{tabular}

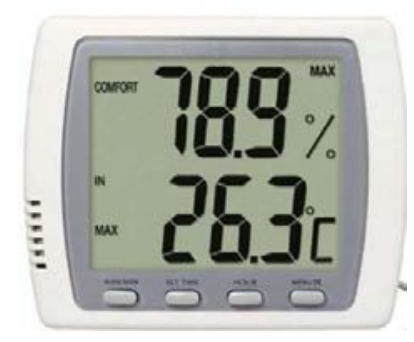

2.Figure. Measuring Device HT-9222

For Liepaja St.Trin., Kuldiga St. Anne, Riga Matthew, Turaida and Riga Jesus Church, measurements were taken with measuring device HT-9222, having accuracy $\pm 3 \%$ for $\mathrm{RH}, \pm 1^{\circ}$ for $\mathrm{T}$. Measurement readings were put down by an especially assigned person in each building and results were written in the log. Next, we gathered and clustered the measurement results. 
Table 6. Time and place of HT-9222 measurements

\begin{tabular}{|l|l|l|l|}
\hline \multicolumn{1}{|c|}{ Church } & $\begin{array}{l}\text { Location of the } \\
\text { measuring device }\end{array}$ & $\begin{array}{c}\text { Interv } \\
\text { al }\end{array}$ & Period \\
\hline Liepaja St. Trin. & $\begin{array}{l}3.5 \mathrm{~m} \text { above the } \\
\text { floor on the } \\
\text { balcony }\end{array}$ & 5 days & $\begin{array}{l}2014.01- \\
2015.12 .\end{array}$ \\
\hline $\begin{array}{l}\text { Kuldiga St. } \\
\text { Anne }\end{array}$ & $\begin{array}{l}3.5 \mathrm{~m} \text { above the } \\
\text { floor on the } \\
\text { balcony }\end{array}$ & 3 days & $\begin{array}{l}2010.09- \\
2011.07\end{array}$ \\
\hline Riga Matthew & $\begin{array}{l}1.5 \mathrm{~m} \text { above the } \\
\text { floor }\end{array}$ & $6 \mathrm{~h}$ & $\begin{array}{l}2008.07- \\
2009.04 .\end{array}$ \\
\hline Turaida & $\begin{array}{l}1.2 \mathrm{~m} \text { above the } \\
\text { floor }\end{array}$ & $\begin{array}{l}1 \text { day } \\
2 \text { days }\end{array}$ & $\begin{array}{l}2011.05- \\
2012.05 .\end{array}$ \\
\hline Riga Jesus & $\begin{array}{l}3.5 \mathrm{~m} \text { above the } \\
\text { floor }\end{array}$ & $6 \mathrm{~h}$ & $\begin{array}{l}2009.01- \\
2011.05 .\end{array}$ \\
\hline
\end{tabular}

\subsubsection{Thermography}

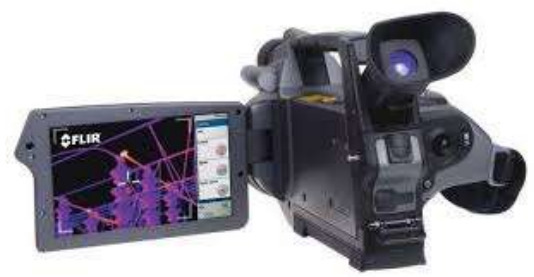

Figure 3. Thermal camera FLIR ThermaCam ${ }^{\mathrm{TM}}$ P640.

Thermal camera calibration Cert. No. F0080K10; 12.01.2010, LNMC

Camera resolution 640x480 pixels;

Spectral range 7.5-13 $\mu \mathrm{m}$;

The emission rate was set to 0.97 .

Thermography was performed in four churches: Cesis St. John, Riga Jesus Church and Krimulda Church, Liepaja St.Trin.

\section{Results}

\subsection{Impact of capillary moisture}

There is no research known regarding evaporation of

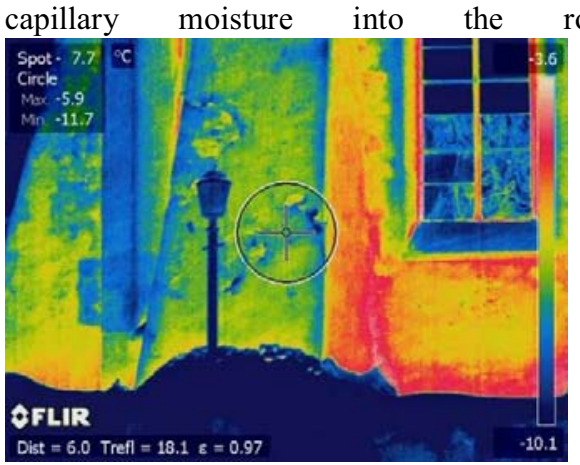

Figure 4. Wall of Cesis Church from outside

Judging from a thermogram taken from the outside of Cesis Church (Fig 4) and Krimulda Church (Fig 5) during winter at temperatures below $-10^{\circ} \mathrm{C}$ and on the building walls above ground level, one can see thermal emissions, which can be explained by the presence of capillary moisture (in the figure below in text). Emission of capillary moisture from the wall in Cesis Church (Fig 4) is observed up to $3 \mathrm{~m}$ above the floor level since the cultural layer has elevated the surrounding ground level at side A of the building by $\sim 1.5 \mathrm{~m}$.

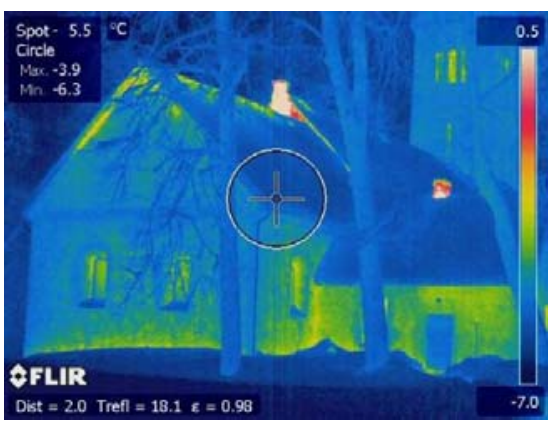

Figure 5. Krimulda Church from outside

Krimulda Church (Fig 5) is situated in a rural area. It does not have a significant cultural layer, which would materially elevate the surrounding ground level. However, the most ancient masonry walls with a thickness of $1.5-2 \mathrm{~m}$ demonstrate a warmer masonry belt right above the surrounding ground level.

\subsection{Zones of church premises and air flows}

When analyzing a typical rural church, compared with Krimulda Church, Sigulda Church, Araisi Church, Limbazi Church etc., the regional rural churches demonstrate the following common picture of temperature divisions in premises used for religious processes (services):

- church attendees mostly use the main entry door thus increasing the inflow of outside air,

- $\quad$ and some of the visitors also need sacristy entry for certain consultations with a minister or other officials of the parish (manager, clerk, churchwarden etc.), also thereby contributing to the inflow of cold air from the opposite side of the church,

- the organist, choir or other parish members use the balcony on the first floor in the parish room, which has a door leading to the tower exposed to outside temperature, - meanwhile in churches with a separate stove-like heating element, often situated between the altar zone and parish zone due to two considerations: to supply radiating heat both to the minister and parish, and historical location of a chimney in the church - it is usually situated in this wall separating the two zones.

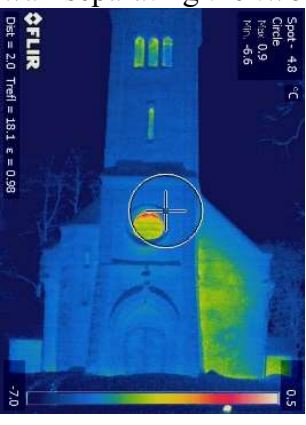

Figure 6. Tower

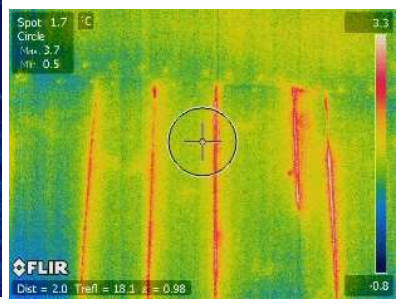

Figure 7. Tower floor in the attic. 

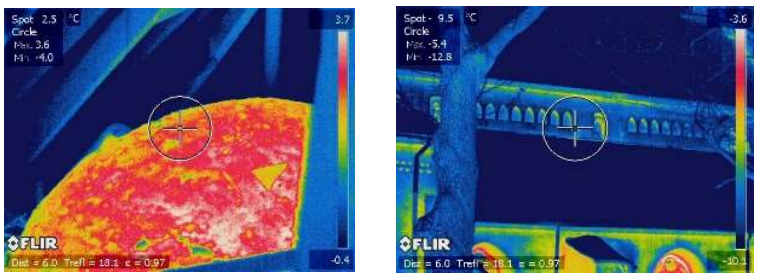

Figure 8. Ceiling vault in the attic Figure 9. Attic from the outside
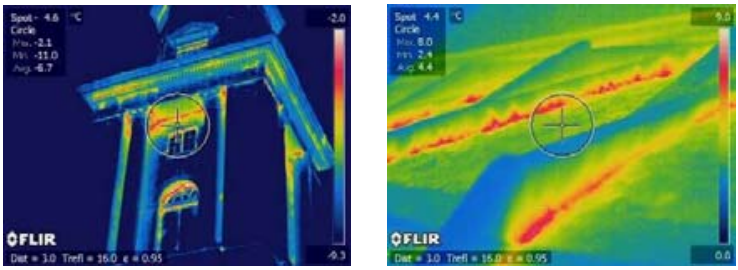

Figure 10. Tower

Figure 11. Dome vault in the attic

- When evaluating the thermograms of Krimulda Church (Fig 6 and 7), Cesis St. John (Fig 8 and 9) and Riga Jesus Church (Fig 10 and 11), taken at air temperature of $-10^{\circ} \mathrm{C}$ it can be established:

- The entire warm air mass ends up at the high ceilings of the room where it further travels to the cold premises and outside through the ventilation grilles in the ceiling or balcony and tower zone, being symbolic cardboard or plywood in the churches under examination. Warm air leaks through the tower can be seen in thermogram taken (Fig. 6 and 10) in Krimulda Church and Riga Jesus Church, and the thermogram shows it escaping through the attic room in Cesis St. John Church (Fig. 9).

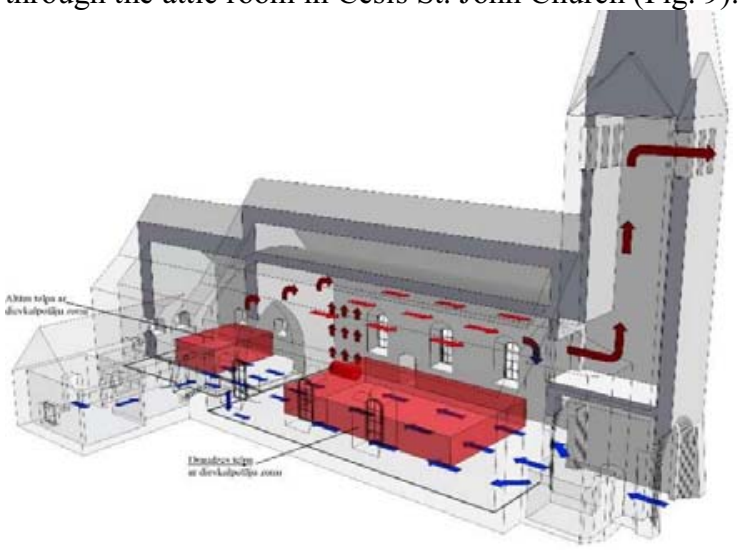

Figure 12. Air flow scheme of Krimulda Church

Church room areas have a virtually created air mass in the room, restricted with building envelopes featuring parallel (vertical, horizontal etc.) lines, keeping in mind that the planned area is actively used in that room. According to the laws of physics, as the air warms up its density decreases, and it rises up to the ceiling and is channeled away in the upper zone. Unlike the Orthodox Lutheran churches, these do not have adjacent monasteries and therefore the variety of rooms is less pronounced, with only one exception - the Riga Dome Church complex which initially was a monastery complex of a Catholic church. A comparison of all the rural churches in Latvia brought us to the conclusion that most of them, $\sim 3 / 4$ of them, are similar in their planning and architecture [14], [15]. So, in order to analyze air flows in the churches, we used Krimulda Church to demonstrate a typical spatial arrangement of churches. Based on this prototype, we created a spatial model (Fig 12) and showed areas of use, the heating element and actual air flows. When describing this model, in a majority of churches there are: longitudinal planning, a tower above the main entrance; at the end of the main entrance of the parish room there is a balcony with an exit to the tower; at the distal end of the parish room there is the altar or a separate altar room; a door leading from the altar or altar room leads to ancillary rooms (sacristy), and the sacristy has a separate entry from the outside.

\subsection{Measurements of brick wall churches}

- Limbazi Church is an architectural monument of national significance, and several art monuments of national significance are situated in it (set of internal doors, set of benches, altar, built-in cupboard). [1] Address: Limbazi, Libiesu Street 2. The church is situated in the center of Limbazi town. The church is surrounded by a church park, situated between streets and a ravine. The church stands on the mound of the old town [12].

The large hall and altar room of the church was not heated initially. The church is being used all year round, i.e. it has bi-weekly services and its doors are open for visitors, without organized gatherings, for the rest of the time. In the winter season, before the services, "infrared lamps", which are situated in the parish hall above the bench rows under the gallery (balcony), are switched on.

Krimulda Church is an architectural monument of national importance [1].

Address: Riga region, Krimulda country, Krimulda parish, Krimulda Church.

Location: $50 \mathrm{~km}$ from Riga, on the side of RaganaTuraida road, in an open field, valley of the Runtins River, from the Southern side with forests in close vicinity.

Two centuries ago, and in the first half of the last century the church was heated with two round stone stoves [12]. Since the 1990s, the church has been heated for the Sunday service, often started in the previous week due to intense cold, and the heating element is an iron stove or so-called large $(\mathrm{d}=0.7, \mathrm{~h}=1.8 \mathrm{~m})$.

Cesis Church is located in the territory of a cultural monument of national significance, whereas the church itself hosts twenty-one individual cultural monuments of national significance [1].

Address: Cesis, Liela Skolas Street 8. The church is situated next to the front of the order's castle, to the southeast, in the middle of the Medieval town, on a block between Torna Street, Liela Skolas Street and Pils Street.

The heating system of the church operates permanently, ensuring between $3^{\circ}$ and $7^{\circ} \mathrm{C}$ on workdays, while the heat supply is increased on Saturday so that on Sunday it reaches approximately $10^{\circ}$ to $14^{\circ} \mathrm{C}$.

Kuldiga Church is an architectural monument of national importance [1]. Address: Kuldiga town, Dzirnavu Street 12. The church is situated in an urban area. [12]

The existing heating system in the church operates irregularly; the church is being heated twice a week, on 
Thursdays and Sundays, trying to keep air temperature at $14^{\circ} \mathrm{C}$.

- The Matthew Church is situated in Riga, Matisa Street 50, in an urban, densely built-up area.

During winter, by setting the maximum heating supply element, the maximum temperature reached for the heated floor was $17^{\circ} \mathrm{C}$. The ceiling of the large hall has natural ventilation flow grilles, which are kept shut for the winter period.

- Liepaja St. Trinity Cathedral is an architectural monument of national significance and it is home to many

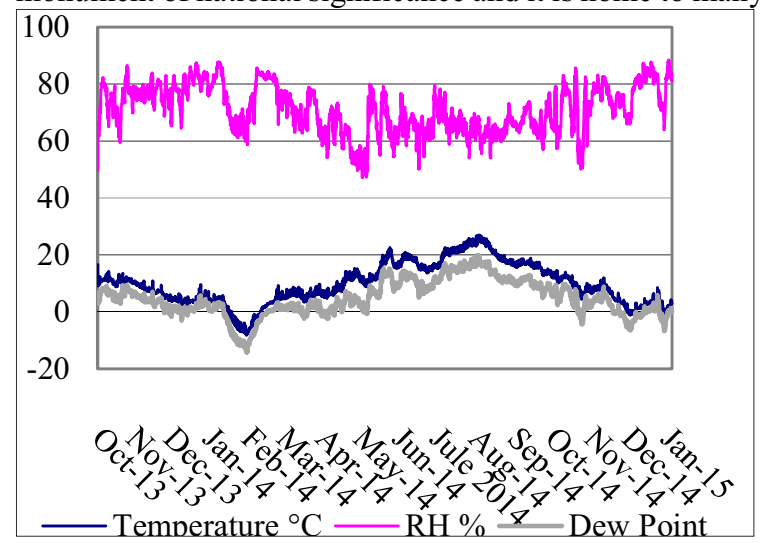

Figure 13. RH and temperature in Limbazi Church (No.1)

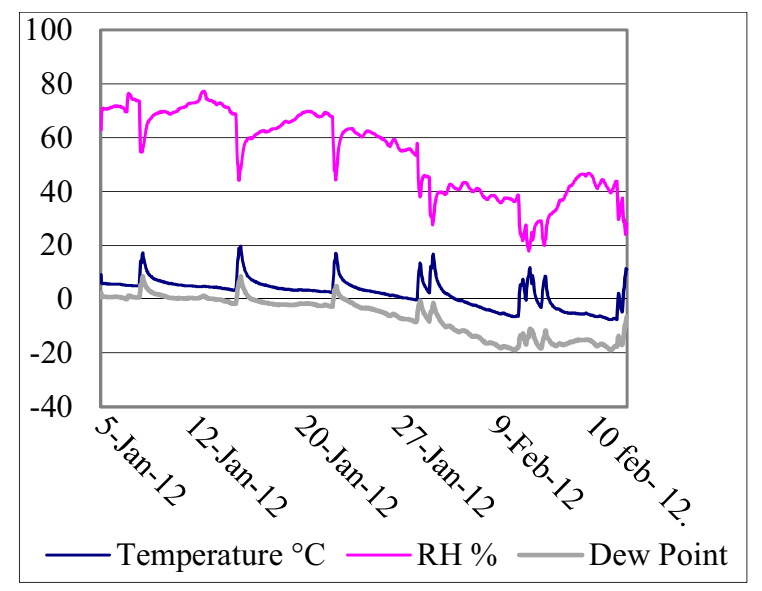

Figure 15. RH and temperature in Krimulda Church (No.1)

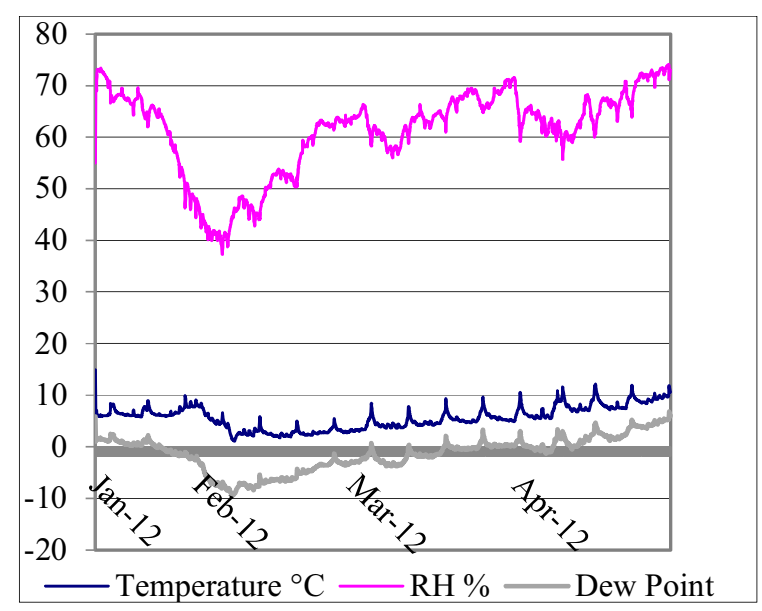

Figure 17. RH and temperature in Cesis St. John Church art monuments of national significance [1]. Address: Liepaja, Liela Street 9. The church is situated in the city centre [12].

The existing heating system of the church is operated in the coldest winter months and it is permanently operational, keeping the average temperature in the premises at $+6^{\circ} \mathrm{C}$. The church is heated for three months per year on average.

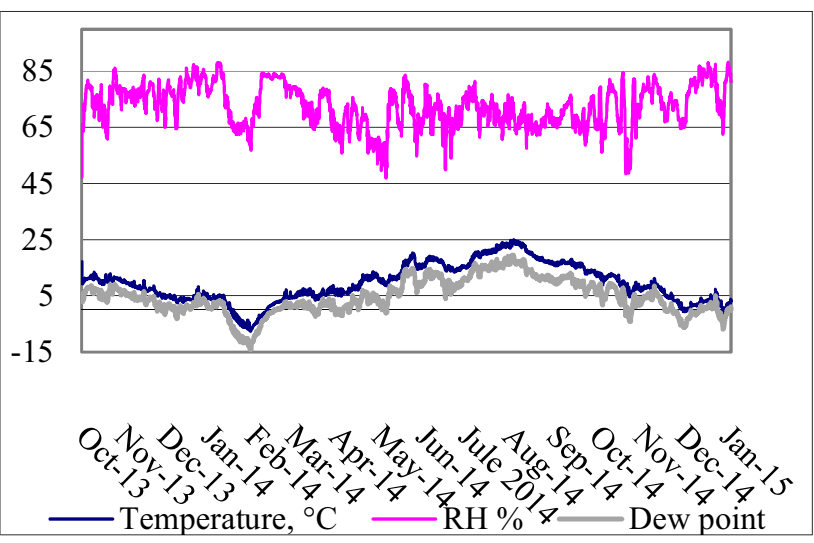

Figure 14. RH and temperature in Limbazi Church (No.2)

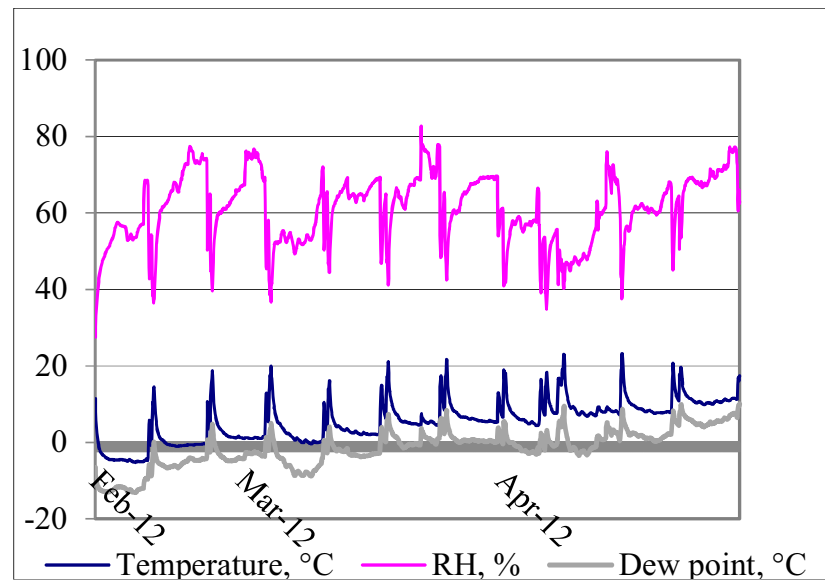

Figure 16. RH and temperature in Krimulda Church (No.2)

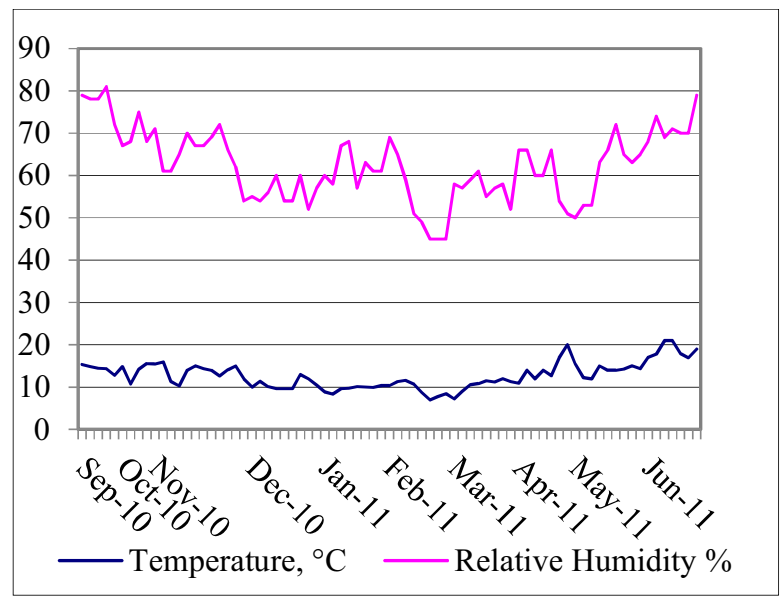

Figure 18. RH and temperature in Kuldiga St. Anne Church 


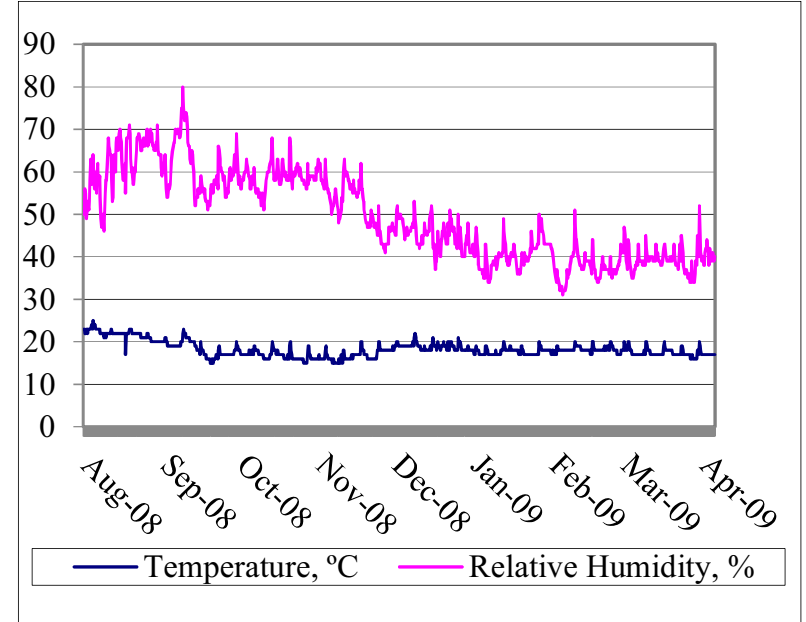

Figure 19. RH and temperature in Matthew Church.

\subsection{Measurements of wooden churches}

- Turaida Church is part of the Turaida museum reserve, which is also an architectural monument of national importance. Address: Riga region, Sigulda town, Turaida Street 10. The church is located in the area of the Turida museum reserve, on an open mound, $\sim 300 \mathrm{~m}$ North from the Bishop's stone palace fortress of the $13^{\text {th }}$ century. [12] The church is not permanently heated, although a hot air generator is used during the cold winter period to heat the air temperature.

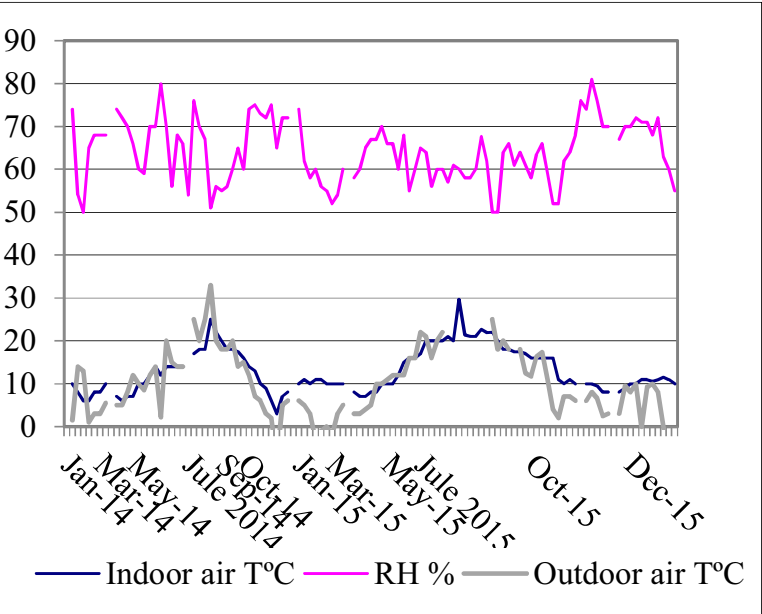

Figure 20. RH and temperature in Liepaja St. Trin. Church

- Riga Jesus Church is an architectural monument of national importance, and there are several art monuments of national importance - organs, interior artefacts situated in it. Address: Riga City, Elijas Street 18. The church is located in the city center at the crossing of Elijas Street and Jesus Street. [12] The church is permanently heated during the cold period, and it also has other administrative rooms which are used during workdays.

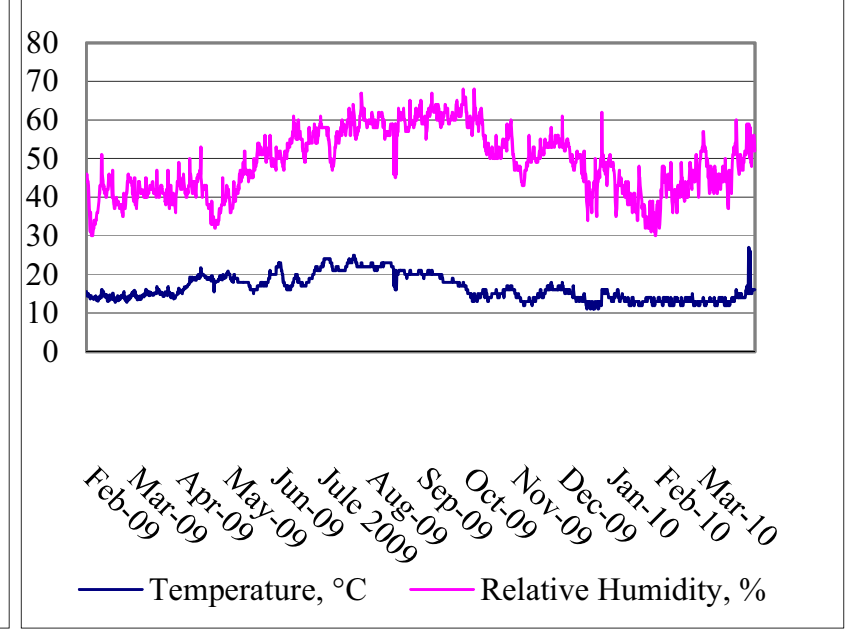

Figure 22. RH and temperature in Riga Jesus Church.

observed only in the case of elevated $\mathrm{RH}$, as is the case in Turaida Church, where $\mathrm{RH}$ reaches $82 \%$. And it is also true for stone churches with the ceiling structures. When comparing the measurement data to the determined condensation temperatures, we see that the main condensation risks are brought by occasional heating, especially for brick wall churches with large masonry wall heat inertia, giving rise to high temperatures and $\mathrm{RH}$ fluctuations, and a high risk of condensation when the heating is re-started. Meanwhile, we see from warm air flows that if the premises have a constant temperature of $+6^{\circ} \mathrm{C}$, the temperature at the ceiling is higher by $+2^{\circ} \mathrm{C}$, 
and thus there are fewer risks of possible condensation. Cesis St. John Church is heated with a heated floor, which ensures an almost permanent inside temperature of $\mathrm{T}$ $+6^{\circ} \mathrm{C}$, and almost equaling the ceiling vault $\mathrm{T}+3.6^{\circ} \mathrm{C}$ at the side of cold attic space (Figure 8), but it also means that condensation does not form on this ceiling from the inside.

We can see from the examined air flows and microclimate measurement observations that outside air infiltration is not actually controlled in any of churches in question, which causes very high inter-seasonal $\mathrm{RH}$ fluctuations.

\subsection{Stone churches}

The intensive use of Limbazi Church produces rapid short-term fluctuations in both temperature and RH. On average, short-term fluctuations of $\mathrm{RH}$ in 24 hours amount up to $15 \%$, but very often they fluctuate twice within $24 \mathrm{hrs}$, which can be explained by the change in frequency of the use of the building, and uncontrolled air admittance into the building. Long-term fluctuations of air parameters in the winter season vary between $-7.6^{\circ} \mathrm{C}$ $\left(31.01 .2014\right.$ RH59.2\%) and $+7.1^{\circ} \mathrm{C}(25.02 .2014 \mathrm{RH}$ $75.6 \%)$; meanwhile, during the summer period between $+13.5^{\circ} \mathrm{C}(24.06 .2014 \mathrm{RH} \quad 66.7 \%)$ and $+25^{\circ} \mathrm{C}$ (04.08.2014 RH 69.6\%). In fact, the highest air parameter fluctuation is achieved during the winter, around Christmas $\left(25.12 .2014 \mathrm{~T}+8.3^{\circ} \mathrm{C}\right.$; $\left.\mathrm{RH} 83.3 \%\right)$ when the church holds several services, and the number of visitors is three times higher than usual. Weather conditions play a significant role in the inside temperature and $\mathrm{RH}$ in rainy periods. Thus, the relative humidity is largely variable, between $47 \%$ and $88.2 \%$. The mean value of $\mathrm{RH}$ is $67 \%$. In fact, the brick structures, due to their mass, accumulate the collected heat very well, so the short-term fluctuations do not cause a frequent change of inside air temperature, whereas the short-term fluctuations of the premises' $\mathrm{RH}$ are significant: On 1 February 2014 at $01: 18 \mathrm{~T}-6.9^{\circ} \mathrm{C}$; $\mathrm{RH}$ $56.8 \%$ while at $15: 18 \mathrm{~T}-6.5^{\circ} \mathrm{C}$ and $\mathrm{RH} 68 \%$ (Fig. 13,14 ). It shows that the church certainly does not have a stable $\mathrm{RH}$, and that use and local heating of the building with infrared heating elements does not provide a stable climate.

Krimulda Church is heated once a week, although it is open to visitors all year round, 24/7. Therefore, the fluctuations are very considerable. Intense heating of the premises for the Sunday's service causes large and rapid short-term fluctuations of both temperature and $\mathrm{RH}$. Temperature varies between $-8^{\circ} \mathrm{C}$ and $+24^{\circ} \mathrm{C}$. Higher air temperatures are achieved in view of the fact that the building is not being heated for the rest of the week, so when the inside air is rapidly heated, the massive brick walls accumulate a much lower temperature causing discomfort and a wish to heat the air even more. Since the church is open $24 / 7$, it is visited almost constantly by tourists, pilgrims (in the winter period $\sim 200$ persons during weekdays, and $\sim 1000$ persons during weekdays in the warm season), and the church has permanent natural ventilation (discussed in previous Sections). The indoor climate of this church is essentially influenced also by the weather conditions - in terms of temperature and relative humidity of the air (rainy season). Thus, the relative humidity is largely variable, between $36 \%$ and $84 \%$. The mean value of $\mathrm{RH}$ is $75 \%$ (Fig. 15, 16). RH standard deviations during this period amount to more than one tenth. This is evidence that the church definitely has no stable $\mathrm{RH}$ and this heating strategy does not provide a stable microclimate.

Cesis Church has the most stable indoor microclimate among the historic churches. Its relative humidity is $55.50 \%$. However, the interval of relative humidity in the heating period is $37 \%$ to $74 \%$, while the short-term fluctuations are $2.1 \%$. In this period the temperature varies between +1 and $+10.5^{\circ} \mathrm{C}$. The average temperature is +7.5 . Temperature fluctuations during weekdays are rather high when the church is not being used, and also on Sunday. Therefore, RH varies between $37 \%$ and $74 \%$. Short-term RH fluctuations are $2.1 \%$ (Fig. 17). Particularly larger fluctuations are observed in periods when the temperature is being constantly increased due to frequency of use of the church.

Relative humidity in Kuldiga Church is less stable than in Cesis Church. This is because the temperature difference between the service and other times of no-usage is much larger. The temperature in the church varies between $+7^{\circ} \mathrm{C}$ and $+19^{\circ} \mathrm{C}$. Since the church measurements were taken on Thursday and Sunday, when the church is being heated, short-term fluctuations are not known. Nevertheless, judging from the experience of church users, the temperature falls to $\pm 0^{\circ} \mathrm{C}$ from Sunday to Wednesday when the heating is re-started. Relative humidity depends on the season. Its mean value in the warm period is $70 \%$. $\mathrm{RH}$ of the church is $52 \%$ in May when the heating season is just finished. Meanwhile between June and October RH stays from $70 \%$ to $80 \%$ tending to increase during later autumn (Fig. 18). RH fluctuations during the heating season vary by an interval of $25 \%$, and therefore $\mathrm{RH}$ can be said to be unstable, which can be explained by periodic heating.

In Matthew Church both short-term and seasonal fluctuations are much lower than in other churches. This building has the most stable indoor microclimate, except for four days from 5 to 9 September 2008 when the relative humidity increases by $10 \%$ in comparison to the remaining period (Fig.19). Since the large hall, just as in other churches, is used on certain weekdays with the heat supply increased for those days, it causes RH fluctuations. It should be remembered that this building is not listed as a historic building as defined earlier by us. Hence the capillary moisture impact and condensation risk calculations do not apply to this building, because this building has different structures.

RH of Liepaja St. Trinity Cathedral varies between $50 \%$ and $80 \%$. Measurements at this church were performed over large intervals and therefore we cannot make a judgement on the short-term microclimate fluctuations in this church, and it is difficult to compare them to measurements of other churches. The temperature varies between $-3^{\circ} \mathrm{C}$ and $+22^{\circ} \mathrm{C}$. $\mathrm{RH}$ fluctuations have a common trend in outside temperature fluctuations, which proves the huge role that the outside air plays in the indoor climate. $\mathrm{RH}$ in the warm season is $60 \%$ on average, whereas it is $70 \%$ in the cold season (Fig. 20). Measurements in this church should be updated after 
renovation of windows and vents at shorter measurement intervals.

\subsection{Wooden churches}

Turaida Church, being a building of the museum reserve, has a relatively large number of visitors. Therefore, the indoor climate of the church is largely influenced by the outside air parameters (temperature and air humidity content). Since a high indoor temperature is achieved with a hot air generator during the cold winter season, it brings about major RH fluctuations of $34 \%$. Even though the condensation risk in wooden churches, as discussed in previous sections, is unlikely to happen, nevertheless rapid and intense heating of the air in the church from $-6^{\circ} \mathrm{C}$ to $+16^{\circ} \mathrm{C}$ increases the condensation risk on the cold structures of the building, causing an airdrying process and also severe fluctuations of relative humidity. Large RH fluctuations from $30 \%$ to $79 \%$ are observed during the warm periods of the year, and they increase warm air flow into the church during the summer up to $27^{\circ} \mathrm{C}$ (Fig. 21). Periodic local heating of the church does not ensure a stable microclimate and, quite the opposite, it increases its fluctuations. The microclimate of this church is very unstable.

The temperature of Riga Jesus Church during the cold season is held permanently between $+10^{\circ}$ and $+15^{\circ} \mathrm{C}$, and in the warm season between $+15^{\circ} \mathrm{C}$ and $28.9^{\circ} \mathrm{C}$, regardless of its use, and it shows the major impact of outside air on the microclimate of the building which causes huge interseasonal changes in relative humidity between $28 \%$ and $70 \%$. The interval of relative humidity in the church during the heating period is $30 \%$ to $50 \%$, while the shortterm fluctuations are $2.1 \%$ (Fig. 22). Short-term RH and temperature fluctuations of the church are relatively small. The indoor climate of this church is stable, with some short-term exceptions in a one-year period, up to ten times, when the temperature suddenly changes by $+5^{\circ} \mathrm{C}$ in 6 hours, which can be explained by deliberate venting.

All the churches also demonstrate outside air infiltration, especially in the case of historic churches (Krimulda, Cesis, Limbazi, Turaida, Riga Jesus Church) and its impact on indoor climate. Therefore, the $\mathrm{RH}$ fluctuation range in all churches is between $28 \%$ and $88 \%$.

\section{Conclusion}

When the buildings are used during the winter, we can see huge inter-seasonal RH fluctuations.

Outside air largely impacts the historic churches due to intense air infiltration.

Judging from the measurements it can be claimed that $\mathrm{RH}$ fluctuations in both stone and wooden churches definitely decrease when permanent conserved heating with minimum air temperatures between $6^{\circ} \mathrm{C}$ and $8^{\circ} \mathrm{C}$ and a maximum low temperature difference for the time of services (air temperature between $10^{\circ} \mathrm{C}$ and $14^{\circ} \mathrm{C}$ ) is maintained.

In general, out of four historic brick wall churches (Krimulda Church, Limbazi Church, Cesis St. John Church, and Liepaja St. Trinity Church), Cesis Church with its average $\mathrm{RH}$ of $55 \%$ has the most stable microclimate due to permanent conserved heating.
Out of two wooden churches the most stable indoor climate is in Jesus Church with the average RH of $49 \%$, where both short-term fluctuations and seasonal fluctuations are much lower than in Turaida Church.

In further research it would be necessary to examine the volume of vaporized capillary moisture and its impact on the indoor microclimate. It would be necessary to continue research of the microclimate in such historic churches which have prevented uncontrolled outside air infiltration through the building envelope, so that a possible microclimate variations simulation could be performed on the basis of data obtained.

\section{References:}

[1] IS "Mantojums" - VKPAIC 2016 https://is.mantojums.lv,

[2] State Inspectorate for Heritage and Cultural Protection DISCUSSION RESOLUTION, „Heating in Historic Church Buildings” 29 July 2008.

[3] Juris Birss «Practical physics for civil engineers. Foundation», 2018

[4] T.Brostrom, J.Hanson „HEATING AND INDOOR CLIMATE IN NINE BALTIC CHURCHES" GU, Dep. of Build. Conserv. 2005.

[5] D.O. Sovetnikov, D.V. Baranova, A. Borodinecs, S.V. Korniyenko „Technical problems in churches in different climatic conditions" Construcion of Unique Buildings and Structures, 2018.

[6] J. Nazarova, A. Borodinecs „Evaluation of Temperature and Humidity Regime in an Orthodox churche", RTU Construction Science, vol.15, no. 1,2014

[7] A. Borodinecs, J. Nazarova, A. Zajacs, A. Malyshev, V. Pronin ,Specifics of Building Envelope Air Leakage Problems and Airtightness Measurements" Paper presented at the MATEC Web of Conferences, 2016

[8] J. Zemitisa, A. Borodinecs, A. Geikinsa, T. Kalameesb, K. Kuusk „Ventilation system design in three European geo cluster" Paper presented at the Energy Procedia, 2016

[9] V. Siniveea, L. Kurika, T. Kalameesb «A simple adaptive ventilation controller for mediaeval church» Energy Procedia, 2016

[10] M. Napp, T. Kalamees «Energy use and indoor climate of conservation heating, dehumidification and adaptive ventilation for the climate control of a mediaeval church in a cold climate» Energy Building, 2015

[11] Regulations on the Latvian Construction Standard LBN 003-19 "Construction Climatology"

[12] V.Masnovskis. «Lutheran Churches of Latvia» Riga. 2007.

[13] A.Caune, I.Ose. «Medieval stone churches of Latvia. $12^{\text {th }}$ century and beginnig of the $16^{\text {th }}$ century » Riga. 2010. 